\title{
Turnout determinants in democracies and in non-democracies ${ }^{1}$
}

\author{
Ferran Martinez i Coma \\ The University of Sydney \\ Department of Government and International Relations \\ The Electoral Integrity Project \\ Phone: 61293512147 \\ Sydney, NSW 2006 Australia \\ ferran.martinezcoma@sydney.edua.u
}

\begin{abstract}
Elections are celebrated in democracies as well as in non-democracies. Studies on the factors explaining turnout normally focus, however, only on democracies. Are turnout patterns different in non-democracies? If so, how different are those? In this paper I address this issue with a unique dataset covering 942 elections in 92 democracies and 477 in 94 nondemocracies for the period 1961-2008. I find that, contrary to expectations, the turnout determinants in both regimes do diverge on the institutional and, to a lesser degree, on the socio-economic factors. In both regimes, the decision of the incumbent to run positively affects turnout.
\end{abstract}

Keywords: turnout, democracies, non-democracies.

\footnotetext{
${ }^{1}$ I am grateful for their comments of earlier versions of this paper to Pippa Norris, Richard W. Frank, Ignacio Lago, Minh Trinh and Pablo Barbera for sharing his data. All the errors are solely mine.
} 


\section{Introduction}

Citizens have lived longer under dictatorships than under democracies. For instance Przeworski, Alvarez, Cheibub and Limongi (2000) study 141 countries from 1950 to 1990 identifying 238 regimes: 105 democracies and 133 dictatorships. In that period, 64\% of the time was lived under dictatorships (3007 years) and 36\% on democracies (1723 years). Elections have been celebrated in both regimes. Literature on turnout, however, has mainly focused on democracies. Are turnout patterns different between democracies and nondemocracies? If so, which are those? In this paper, with a unique dataset, I address those issues.

I argue that when analyzing determinants of turnout, non-democracies should also be considered for two main reasons. First, from a scholarly perspective, I want to disentangle whether the determinants for turnout are the same as in democracies. This will be a signal of how robust the classical explanations are. Considering democracies and non-democracies jointly, will improve our understanding to disentangle the factors affecting turnout and obtain the most encompassing explanation. The second reason is that since non-democracies are not distributed randomly around the world, my sample of 942 elections for 92 democracies and 477 elections for 94 non democracies can reduce the bias present in the literature. As I will show later, there is no reason to argue that some of the most common hypothesis should behave differently in democracies than in non-democracies.

With a unique dataset covering the 1961-2008 period, I compel more definitive evidence about some of the explanations on turnout available on the literature. The findings point that, contrary to what could be expected, democracies and non-democracies, barely share any explicative factors. The most important divergences are found on the institutional variables: in democracies compulsory voting and voting in parliamentary elections increase turnout, 
while in non- democracies not. The common shared element among regimes is a political factor such as the incumbent running and in both cases positively affecting turnout.

The rest of the paper proceeds as follows. In the second part I discuss in detail the reasons for studying turnout in democracies jointly with non-democracies. In the third section I present the dataset and the methods. The fourth section discusses the results, while the fifth concludes.

\section{Turnout in democracies and in non-democracies}

Elections are crucial to the legitimacy of democracies and, in that regard, voter turnout is determinant since it is an important dimension of the quality of democracy (Altman and Pérez-Linan, 2002). Turnout has been used as an indirect measure of popular legitimacy (Lijphart, 1999) and some have rightly argued that "elections are at the core of modern democracy, and low voter turnout rates might indicate that people do not see elections as central to political life” (Kuenzi and Lambright, 2007: 665). Recent years have also seen growing concern about declining turnout in established democracies (Franklin, 2004), regarded as part of a broader process of civic disengagement which is particular common among the younger generation (Blais, Gidengil and Nevitte, 2004).

Turnout, however, is also very important in non-democracies since it allows the regime to obtain valuable information about its supporters and opponents (Magaloni, 2006) or its local officials (Geddes, 2005). Blaydes (2006) has also argued that elections in non-democracies are used as a mechanism to resolve “intra-elite conflicts”. Turnout also may legitimate autocrats internally. Despite its importance, Gandhi and Lust-Okar (2009: 414) state that "what is striking about the literature to date is that electoral behavior in authoritarian regimes is similar in many ways to that in democracies.” In this line of argument, I propose that in 
order to consider the robustness of some hypothesis, turnout should be tested considering democracies and non-democracies.

There are at least three reasons for studying turnout jointly in democracies with nondemocracies. First, many of the factors considered in the explanations are mechanical, independently of whether they are democracies or non-democracies. Explanations of turnout have been normally classified on three categories: the socioeconomic environment, institutions, and political or party systems (Blais and Dzrobinska, 1998). The first explanation, the socio economic, considers the broad social environment in which the election takes place. If socio economic variables, such as population size, concentration, stability, homogeneity, income or previous turnout, have an impact on turnout in democracies, there is no reason to think that they do not in non-democracies. The same argument applies with institutional explanations. If voting is compulsory, the effect on turnout should be the same, regardless the regime. Hence, there are some common elements affecting turnout both in democracies and non-democracies.

Second, testing the available hypothesis in the literature in a more diverse setting could increase their robustness. Moreover, I want to disentangle the factors affecting turnout and obtain the most encompassing explanation possible: considering democracies and nondemocracies jointly will improve our understanding. That is a necessary step since the most relevant studies explaining turnout at the aggregate level have focused on democracies. For instance, in his 2006 paper, Geys reviews 83 studies, all of them democracies. In other works, Blais and Carty (1990) include 509 elections to the lower house for 24 countries, all democracies; Blais and Drozbynska (1998) include 324 elections to the lower house held in 91 countries, all democracies; Franklin (2004) covers 356 elections to the lower House elections of the national legislature in 22 democracies for the 19451999 period; and 
Stockmeier and Calca (2012) use more than 450 democratic legislative elections for 114 countries between 1990 and $2010^{2}$.

Third, it is very relevant to learn whether there are different patterns on turnout between democracies and non-democracies. In that regard, the political factors -those related to the electoral race as well as the political landscape (Geys, 2006)- could impact turnout differently in democracies to non-democracies. Consider the office of the incumbent being contested in the election. The logic for both citizens and politicians is different. Citizens in a democracy can lay on the reward/punishment logic: they vote to the party or candidate in office if she considers that the government has done a good job; otherwise she can decide to vote for the opposition (Key, 1966). But this logic may not hold in a non-democracy since, in the end, the office of the incumbent may not even be contested.

Besides, the uncertainty that is present when the office is contested is higher in a nondemocracy since there is more room for 'surprises'. To mention just a few (and not exhaustively), when the incumbent in a non-democracy steps down from power, he may hand the power to his son (in Azerbaijan Ilham Aliyev succeded his father Heydar Aliyev); a transition arrives (such as in Chile after Pinochet); or he is overthrown of power by another military (such as Stroessner with Rodríguez in Paraguay initiating the transition to democracy). Overall, it is not clear that if the incumbent runs in a non-democracy, turnout is higher. In a democracy, by definition, the office of the incumbent is contested. When the incumbent does not run again she either reached her term limit (as in the United States); she does not have the support of her party any more (as Julia Gillard in Australia) or renounces to continue in power (as Chirac in France).

\footnotetext{
${ }^{2}$ Only considering democracies is also very present at the individual level. For instance, when analyzing the determinants of turnout at the individual level, Smets and van Ham (2013) review 90 studies, all democracies.
} 
In a nutshell, I argue that when analyzing turnout, scholars should study democracies jointly with non-democracies. And at least, there are three reasons for this. First, many of the factors laid out in the economic and the institutional explanations work mechanically, independently of whether they are democracies or non-democracies. Second, to disentangle the factors affecting turnout and obtain the most encompassing explanation possible: considering democracies and non-democracies jointly, will improve our understanding. Third, methodologically, by expanding the coverage of the countries and the type of elections included in the analysis I can be more confident about the generalization of the results.

\section{Data and Estimation}

The dependent variable is turnout rate. As Geys explains, the definition of turnout varies; while in almost the majority of the studies the numerator is the number of valid votes cast, there are differences regarding the denominator: voting age population, number of eligible voters, number of registered or the size of the electorate. I have defined turnout as the number of votes cast divided by the voting age population, since it is the most common in the literature ${ }^{3}$. Moreover, by considering the Voting Age Population (VAP), which includes all citizens above the legal voting age, I avoid the use of registration figures and, also, those figures can "provide a clearer picture of participation as they signal a problem with the voters' register or registration system” (IDEA Glosary). This is a difference worth mentioning because there may be divergences with the official statistics reported in many countries. Registration processes may also exclude a substantial slice of the population, such as women (in Saudi Arabia), or the prison population in the US (Macdonald and Popkin, 2001).

I have obtained the dependent variable from the Institute for Democracy and Electoral Assistance (IDEA) website on voter turnout. The data is presented country by country and

\footnotetext{
${ }^{3}$ In other words, our definition of turnout matches theirs of 'Vote/VAP', which is the most common in the academic literature. http://www.idea.int/vt/glossary.cfm\#Voter Turnout
} 
differentiates between registered voters as well as voting age population. The elections included are those held after 1945 for national for national political office in independent nation states ${ }^{4}$ with more than one party -or one party and independents or just independent candidates- contesting the elections ${ }^{5}$ and where the franchise was universal. ${ }^{6}$ I include both executive and legislative elections in the dataset.

The dependent variable is composed of 2,337 elections from 184 countries covering the 1945-2013 period. Voting is compulsory in less than 30\% of the elections and about a fourth are presidential; $31 \%$ of the elections in the sample are in non-democratic regimes, the mean turnout for which is $57.8 \%$, significantly lower than the $67 \%$ in democracies.

I have graphed the respective turnout rates for democracies and non-democracies from 1945 until 2008. I understand democracy as Cheibub, Gandhi and Vreeland ${ }^{7}$ (2010) acknowledging that it is not the only definition available ${ }^{8}$. The horizontal axis represents the year of the election while the vertical axis depicts the turnout rate. Today, only a few countries, such as Saudi Arabia or Brunei, lack elective national assemblies (Norris, 2014).

\footnotetext{
${ }^{4}$ With the exception of nations which held elections on the eve of their independence from colonial rule (such as Nigeria in 1959), those small island nations whose sovereignty is limited by "free association" with a larger power (such as Aruba) or elections to the EU parliament

${ }^{5}$ This excludes the one-party states of North Korea, China, and the Soviet Union, but includes elections such as Uganda 1995 (where parties were banned) and Egypt 1976 where a number of independent candidates ran against the ruling party. IDEA included those cases that would fall into the grey area of competitiveness, at least where the data is available.

${ }^{6}$ IDEA also includes Liechtenstein (pre-1986), Switzerland (pre-1971), Greece (pre-1956), Belgium (1948), Kuwait (1992-1996), Bahrain (1973) and Argentina (1947) which excluded women from voting. In these cases, the voting age population figure only includes men. However, elections where the franchise was limited to a very small (and ethnically defined) segment of the population, e.g., South Africa (before 1994), Western Samoa (before 1991) are not included.

${ }^{7}$ According to Cheibub, Gandhi and Vreeland: “A regime is classified as a democracy if it meets the requirements stipulated in all of the following four rules:

1. The chief executive must be chosen by popular election or by a body that was itself popularly elected.

2. The legislature must be popularly elected.

3. There must be more than one party competing in the elections.

4. An alternation in power under electoral rules identical to the ones that brought the incumbent to office must have taken place.” (2010:69)

${ }^{8}$ In fact, when checking the robustness of the findings, I use other definitions of democracy.
} 
Graphs 1 and 2 about here

The graphs include information for 1924 elections: 1335 in democracies and 589 in nondemocracies. First, it does not seem that turnout in non-democracies behaves substantially different than in democracies. Second, since 1990, the number of elections has increased and elections seem to be the norm rather than the exception. Third, democracies and nondemocracies show important dispersions on their respective turnout patterns but not very different among themselves. For instance, turnout was as low as 2.1 per cent for the general elections of December 1983 in Jamaica, given the opposition boycott, to the 92 per cent for the general elections of October 2004 in Uruguay, where voting is compulsory. Nondemocracies also show an important variation: Kuwait elections of 1981 and 1985 reached a turnout of 8.2 and 8.4 per cent, respectively, on a striking contrast with the 100 per cent on the general elections of the Dominican Republic in 1952. Comparing the lower bounds along the 1945-2008 period, there are 11 elections in democracies (not even a 1\%) that reached a participation of less than 20\% while there are 20 in non-democracies (almost 3.4\%).

Data for the independent variables come from multiple sources, but mainly from two datasets. The first dataset is compiled by The Quality of Governance (QoG) Institute at the University of Gothenburg (Teorell et al, 2013). Their Standard Dataset 2013 is a crosssectional time-series dataset with global coverage spanning the time period 1946-2012. QoG is very detailed and allows the inclusion of some variables for an important number of explanations. Since QoG contains multiple data series with different coverage for some measures, for instance GDP, it allows the combination of these series to expand the data coverage. The second dataset, the National Elections Across Democracy and Autocracy (NELDA), is developed by Susan Hyde and Nicolay Marinov (2012) covering all states with a population above half a million in existence for any period between 1945 and 2006 are 
included. I also made use of Susan Hyde, Hafner-Burton and Jablonski’s expansion of NELDA in 2013.

The independent variables in the analysis can be grouped into three main categories: socioeconomic, institutional, and political. Socio-economic variables account for explanations of turnout that look at the socio-economic conditions facing the voters. Geys mentions five socio-economic variables that have been associated with voter turnout: "population size, population concentration, population stability, population homogeneity and previous turnout levels” (2006:641). The effect of population size has been established by current literature to be negative and negatively correlated with turnout (Blais and Dobrzynska, 1998; Blais and Carty, 1990). At the same time, there seems to be no evidence supporting "the idea that population concentration reduces turnout” (Geys, 2006:643). In the same line, there seems to be not a very strong relationship on the debated hypothesis of population homogeneity while it seems that population stability positively affects turnout (Geys, 2006: 644). Also, as many have found, voting may be a habit and past turnout has been found to significantly impact turnout (Aldrich, Montgomery and Wood, 2010). Lastly, it is also the case that GDP is present in some studies and the findings are that "economic development does seem to facilitate turnout” (Blais and Dobrzynska, 1998:243).

To test these socio-economic explanations, I include measurements of them in the analysis. While population stability has to be excluded due to lack of data, for population size, concentration, and homogeneity - I rely on the QoG dataset. Data for population size comes from five series within this dataset - Maddison (Bolt and van Zanden, 2013), Gleditsch (2002), Penn's World Tables, World Development Indicators, and United Nations, with the value for each observation being calculated as the mean of every series that is available for it. To measure population concentration size, I use the World Development Indicators measure of the percentage of people living in urban areas, while the measure of ethnic 
fractionalization comes from Alesina, Devleeschauwer, Easterly, Kurlat and Wacziarg (2003) measure of ethnic fractionalization supplies data for the population homogeneity variable. For the GDP measure, I use the logarithm of GDP at purchaser’s price from the World Bank provided by QoG. The value of past turnout can be calculated manually, but I excluded it from the main analysis. As a lagged term of the dependent variable, it has the tendency to soak up the explaining power of relatively static factors such as institutions, population concentration or homogeneity (Achen, 2001). I do, however, include it in the robustness checks.

On the institutional explanations, the variables that have been signaled are: whether the vote is compulsory or not; the type of electoral formula; whether the elections were concurrent or not and registration requirements. I include whether voting is compulsory or not, one of the most solid findings in the literature: when voting is compulsory, turnout is higher (Blais, 2006). I also include whether the election was parliamentary or presidential (Stockemer and Calca, 2012). Data to test both hypotheses come from International IDEA.

The electoral system is a relevant variable on the institutional explanations, but its meaning differs for the legislative and presidential elections. Available measures of the electoral system account only for the legislative elections, whereas my analysis attempts to include both types of elections. The same applies to the number of parties, an oft-mentioned variable of which impact is still inconclusive (Blais, 2006). I do, however, include these variables in a model restricted only to legislative elections as a robustness check. In the QoG dataset, this variable comes from Matt Golder's and Nils-Christian Bormann 2013 dataset. Since this series contain only data for elections in democracies, I supplemented it with data collected by Pablo Barbera (2012). ${ }^{9}$

\footnotetext{
${ }^{9}$ Since Barbera based his measure on the classification of Golder's earlier work (2005), I recoded his series from a 5-class scale to the simplified 3-class scale of Golder 2013.
} 
Variables pertaining to political explanations are much more difficult to include in the model, mostly due to data availability: standard measures of campaign expenditures, for example, are not easily obtained. The reliability of such measures in less transparent regimes can also be seriously questioned. Other measures are ex post: the competitiveness, measured as the gap in vote shares between the first and the second party, uses the results of the election as a variable (after voting), to measure the turnout (previous to the result).

I therefore propose a more basic approach by including an indicator pointing out if the office of the incumbent was being contested in the election as the only political variable, assuming that if it is the case, turnout will be higher. The logic is this: if the office of the incumbent is being contested, voters have the opportunity to reward or punish his (or his party's) performance, which may drive turnout upward. Data for this variable comes from the NELDA dataset. ${ }^{10}$ Table 1 presents a description of the variables used for the analysis.

\section{TABLE 1 ABOUT HERE}

\subsection{Estimation procedure}

Two common challenges of analyzing panel data are the issues of time-serial dependencies and correlated error terms within panels. To correct for these, I employ a linear regression model with panel-corrected standard errors that are further corrected for panel-specific AR1 autocorrelation. This model retains cross-country effect, while takes into account the effect of time-serial dependencies.

Franklin (2004) suggests the incorporation of a lagged dependent variable if theoretically valid, but in this situation this is not clear. On one hand, past turnout can be a determinant of current turnout; on the other, a lagged dependent variable soaks up the explaining powers of

\footnotetext{
${ }^{10}$ I follow Hafner-Burton, Hyde and Jablonski (2013) and include Nelda20 measuring whether the office of the de facto leader (usually the president or prime minister) was at stake in the election.
} 
static institutional variables producing an incomplete picture and inflating the amount of variation explained (Achen, 2001). As explained above, I decided to exclude it in the main model, but used it in a later robustness check - the results are found to be similar. I also exclude country dummies following the same logic: including them tend to inflate the models’ explaining power in an illusory manner.

To isolate the effect of the independent variables in non-democracies, I run the models over three separate subsets of data: one including only democracies, another including only nondemocracies, and a third including the entire dataset. Presenting separated models for democracies, non-democracies and together is appropriate since it allows me to compare the models with the traditional results of the literature. Differentiating democracies from nondemocracies will show how well the different explanations perform.

\section{Results}

Table 2 presents the results. Model 1 tests the hypothesis for democracies; model 2 for nondemocracies while model 3 includes both democracies and non-democracies. The period of the analysis covered is 1961-2008 and there are 92 countries included for democracies, 94 for non-democracies and 147 when including democracies and non-democracies. The results for democracies (model 1) point out the validity of the explanations provided by the literature. Regarding the socio-economic variables, the larger the population is, the lower the turnout. Those results are the same as Blais and Dobrzynska (1996) and Blais and Carty (1990). I also find that population concentration positively affects turnout and, as in Geys review, population homogeneity negatively affects turnout. On the institutional explanations, I find that compulsory voting positively affects turnout. Moreover, if the election is parliamentary turnout is higher than if the election is presidential. Finally, the proposed political variable, 
whether the incumbent runs, positively affects turnout. It could be interpreted as a support for the reward/punishment logic mentioned earlier.

\section{TABLE 2 ABOUT HERE}

The results for non-democracies in model 2 are different than for democracies: contrary to model 1, the more concentrated the population is, the lower the turnout. Also, among the socio-demographic variables, population homogeneity and population size are not significant now. The logarithm of GDP has a positive sign, though it is not significant.

The most important differences among regimes, though, lie on the institutional factors. While in democracies compulsory voting and voting in parliamentary elections increase turnout, in non- democracies none of those variables are significant now. This is a major difference among the factors explaining turnout among regimes.

The political variable is significant as in democracies: if the incumbent decides to run, turnout is higher. And this variable is the only one behaving equally across the two regimes as can be seen in model 3 where democracies and non-democracies are considered jointly. Model 3 also shows that democracies have a significantly higher turnout.

Hence, democracies and non-democracies contrary to what was pointed above, barely share any explicative factor on turnout. The only common element shared among regimes is whether the incumbent runs: in both cases, turnout is higher. However, the main differences are in the institutional structure and the socio-economic factors.

\subsection{Robustness checks.}

I have done three robustness checks. The first is changing the definition of democracy that I have been using for the analysis from that of Cheibub, Gandhi and Vreeland (2010). Now I use the imputed version of Hadenius and Teorell (2005) who transformed Polity and Freedom 
House Index. Hadenius and Teorell show that their average index performs better both in terms of validity and reliability than its constituent parts. The second robustness check includes the electoral formula as well as the number of political parties in the analysis. This has the limitation that I only consider elections for the legislature, in the same vein as Blais and Dobrzynska (1998) or Stockmeier and Calca (2012). Finally, I also include the previous turnout level in the analysis.

I have codified the other definition of democracy variable in two different ways ${ }^{11}$ and the results are substantially the same as in table 2. Models 4 and 5 in table 3 show how different definitions of democracy point out the same result and should be compared with model 3: turnout is higher in democracies than in non-democracies. It is also the case that when the incumbent runs, turnout is higher. The number of cases of models 4 and 5 are lower than for model 3 because the years covered are from 1972-2011.

Although I only report the joint models ${ }^{12}$, the democracy and non-democracy models are similar to models 1 and 2 in table 2 . The most important findings, on the institutional differences and the political similarities, hold, though not perfectly: compulsory voting is significant two out of the three different democracy definitions. On the socio-economic variables, population concentration behaves equally. But while in table 2, population homogeneity had the same sign in non-democracies than in democracies but it was not significant. Now it is also significant in non-democracies. Also, population size is not significant in neither of those models nor for any of those regimes.

\section{TABLE 3 ABOUT HERE}

\footnotetext{
${ }^{11}$ I have defined such variable 'democracy2' as a dichotomous variable. It has a value of 1 if it scores 8 or higher; 'democracy 3 ' has a value of 1 if it scores 7 or higher.

${ }^{12}$ The data set is available in XXXX website for purposes of replication.
} 
For the second robustness check (model 6) I have included the electoral formula as well as the number of parties. In this case, only the elections to the legislature are included and the number of cases included in the analysis is reduced. Majoritarian systems negatively affect turnout very strongly in non-democracies (not reported) but not significant in democracies. The number of parties do not impact turnout. The rest of the results are quite similar to those of table 2, and the differences on institutional and the similarities on political variables hold. Democracy has a positive impact on turnout compared to non-democracies. Compulsory voting is significant in democracies but not in non-democracies and turnout is also positively affected if the incumbent runs again for office. The previous findings regarding the socioeconomic variables are also consistent: population homogeneity negatively affects turnout in democracies but does not have an impact in non-democracies. Coincidence, though, it is not exact: now also in non-democracies, population homogeneity is negatively significant reducing turnout.

For the final robustness check (model 7), I have considered the inclusion of the previous turnout level. As explained, this variable has been proven to be significant in the literature and could be included in the original model. But as mentioned above, the problem including an independent variable as a lagged version of the dependent variable, as this case, is not only that it can inflate the variance explained but also "depress estimates of the effects of other independent variables” (Franklin, 2004: 127). The inclusion of the previous turnout may explain why the democracy variable is not significant now: basically, previous turnout captures all the variance of the variables that are almost time invariant, as democracy.

The results of the rest of the variables are similar as in the rest of the models. Regarding the socio-economic variables, population homogeneity behaves as in table 2: it negatively affects turnout in democracies but not in non-democracies and when jointly considered. Compulsory voting also behaves as in table 2 but the type of election now is also significant for non- 
democracies. Finally, on the political variables, the incumbent running positively affects turnout a result consistent in all the model specifications. If after considering the previous turnout, those variables are also significant, results seem to be robust.

It is worth to recapitulate the overall results. In democracies, I have found that 1 ) the larger and the less homogeneous is the population, the lower the turnout. However, the more concentrated the population is, the higher the turnout; 2) compulsory voting positively affects turnout and turnout is higher in parliamentary than in presidential elections. 3) The decision of the incumbent running positively affects turnout and this finding also holds for nondemocracies. This is one of the few common elements explaining turnout in both regimes. Those results hold after three different robustness checks- a different definition of democracy; the inclusion of the electoral formula and the number of parties; and the turnout rate of the previous election.

\section{Conclusions}

Elections also are held in non-democracies but normally only turnout in democracies is analyzed. In this paper, I have started to overcome this gap by analyzing the turnout factors affecting both in democracies and in non-democracies. This is a first attempt to my knowledge to explain turnout in a more comprehensive way by including democracies and non-democracies. To do so, I have created a unique dataset with 946 elections in democracies and 486 in non-democracies for the 1961-2008 period.

Overall, there are three main highlights. First, democracies and non-democracies contrary to what was expected, barely share any explicative factors on turnout. More importantly, their most important differences are on the institutional variables: in democracies compulsory voting and voting in parliamentary elections increase turnout, while in non- democracies not. 
Second, the only common shared element among regimes is political: when the incumbent runs turnout is positively affected. Third, on democracies, the findings are in accordance with previous works in the literature, especially on the socio-economic and the institutional variables. This is worth to stress since my sample is more diverse, pointing out the strengths of the hypothesis. The respective controls -with different definitions of democracy, the inclusion of the electoral formula, the number of parties as well as the previous turnout rate, although not perfectly, seem to confirm the results.

The results are relevant in two ways. First, they show that there are distinctive turnout patterns among regimes, although contrary to the initial expectations. Second, to my knowledge, this is the first study to include the factors explaining turnout for nondemocracies.

However, there are more questions that need to be considered. This is just the first step and future research could focus on expanding the elements affecting turnout. I have proposed one new element on the political explanations: whether the incumbent runs. This is not the only political variable that may affect turnout since probably other elements such as corruption (Stockemer, LaMontagne and Scruggs, 2012), media relevance or the integrity of the election may impact turnout. Probably, it could be considered a wider scope regarding the political variables. In the same line of argumentation, I have only focused on the most used variables both in the socio-economic and institutional explanations and probably including other variables may be relevant. Future research could also address the distinct factors that drive turnout in both regimes: I have identified one of the common elements for the two regimes but more work needs to be done to disentangle the specific patterns for each system, especially in non-democracies. 


\section{Acknowledgments}

I am grateful for their comments of earlier versions of this paper to Pippa Norris, Richard W. Frank, Ignacio Lago, Minh Trinh and Pablo Barbera for sharing his data. All the errors are solely mine.

\section{References}

Achen, C. 2001. Why Lagged Dependent Variables Can Suppress the Explanatory Power of Other Independent Variables Paper prepared for the Annual Meeting of the Political Methodology Section of the American Political Science Association. http://www.princeton.edu/csdp/events/Achen121201/achen.pdf

Aldrich, J., Montgomery, J. and Wood W. 2011. “Turnout as a Habit”, Political Behavior, Volume 33, Issue 4, pp 535-563.

Alesina, A., Devleeschauwer, A., Easterly, W., Kurlat, S., and Wacziarg, R. 2003. Fractionalization. Journal of Economic Growth, 8: 155-194.

Altman, D., and Pérez-Liñán, A. 2002. Assessing the Quality of Democracy: Freedom, Competitiveness and Participation in Eighteen Latin American Countries. Democratization, 9(2): 85-100.

Barbera, P. 2012. When Duverger Becomes Autocratic: Electoral Systems and Opposition Fragmentation in Non-Democratic Regimes, 1950- 2008. Paper prepared for the 22nd World Congress of Political Science, July 2012.

Blais, A. 2006. What Affects Voter Turnout? Annual Review of Political Science, 9: 111-25.

Blais, A., and Carty, R. K., 1990. Does proportional representation foster voter turnout. European Journal of Political Research 18, 167-181.

Blais, A., and Dobrzynska, A. 1998. Turnout in electoral democracies. European Journal of Political Research 33, 239-261. 
Blais, A., Gidengil, E., and Nevitte, N. 2004. Where does turnout decline come from? European Journal of Political Research 43, 2: 221-236.

Blaydes, L. 2006. Who Votes in Authoritarian Elections and Why? Determinants of Voter Turnout in Contemporary Egypt Paper presented at the Annual Meeting of the American Political Science Association.

Bolt, J. and van Zanden, J. L. 2013. The First Update of the Maddison Project Re-Estimating Growth Before 1820. Maddison-Project Working Paper 4.

Bormann, N-C. and Golder, M. 2013. "Democratic electoral Systems Around the World, 1946-2011." Electoral Studies, 32: 360-369.

Cheibub, J. A., Gandhi, J., and Vreeland, J. R. 2010. Democracy and dictatorship revisited. Public Choice, 143:67-101.

Cox, G. W., Munger, Michael, C., 1989. Closeness, expenditures and turnout in the 1982 US house elections. American Political Science Review 83 (1), 217-230.

Franklin, M. 2004. Voter Turnout and the Dynamics of Electoral Competition in Established Democracies Since 1945. Cambridge University Press.

Gandhi, J. and Lust-Okar, E. 2009. Elections Under Authoritarianism. Annual Review of Political Science, 12: 403-22.

Geddes, B. 2005. Why Parties and Elections in Authoritarian Regimes? Paper presented at the Annual Meeting of the American Political Science Association.

Geys, B. 2006. Voter turnout: A review of aggregate-level research. Electoral Studies, 25, 637-663.

Gleditsch, K. S. 2002. “Expanded Trade and GDP Data.” Journal of Conflict Resolution, 46: 712-724.

Golder, M. 2005. Democratic electoral systems around the world, 1946-2000. Electoral Studies, 24, 103-121.

Hadenius, A. and Teorell, J. 2005. Assessing Alternative Indices of Democracy Political Concepts Committee on Concepts and Methods Working Paper Series 
http://www.concepts-

methods.org/Files/WorkingPaper/PC\%206\%20Hadenius\%20Teorell.pdf

Hafner-Burton, E. M., Hyde, S. and Jablonski R. 2014. "When Do Governments Resort to Election Violence?” British Journal of Political Science, Volume 44, Issue 01 pp 149179.

Hyde, S. and Marinov, N. 2012. “Which Elections Can Be Lost?”, Political Analysis, 20(2), 191-201.

Jackman, R. W. and Miller, R. A. 1995. "Voter Turnout in the Industrial Democracies during the 1980"”. Comparative Political Studies 27: 467.

Key, V. 0. 1966. The Responsible Electorate. Cambridge, MA: Harvard University Press.

Kuenzi, M., and Lambright, G. M. 2007. Voter Turnout in Africa’s Multiparty Regimes. Comparative Political Studies, 40(6): 665-690.

Laakso, M., and Taagepera, R. 1979. "The "Effective" Number of Parties: "A Measure with Application to West Europe", Comparative Political Studies, 12:1

Lijphart, A. 1999. Patterns of Democracy: Government Forms and Performance in Thirty-six Countries. New Haven, CT: Yale University Press.

Magaloni, B. 2006. Voting for Autocracy: The Politics of Party Hegemony and its Demise. Cambridge University Press.

McDonald M. P. and Popkin, S. 2001. "The Myth of the Vanishing Voter." American Political Science Review 95(4): 963-974.

Norris, P. 2014. Why Electoral Integrity Matters. Cambridge University Press.

Przeworski, A., Alvarez, M., Cheibub, J. A. and Limongi F. 2000. Democracy and Development: Political Institutions and Well-Being in the World, 1950-1990. Cambridge: Cambridge University Press.

Smets, K., and van Ham, C. 2013. “The embarrassment of riches? A meta-analysis of individual-level research on voter turnout” Electoral Studies, 32: 344-359. 
Stockemer, D., and Calca, P. 2012. Presidentialism and Voter Turnout in Legislative Elections. Parliamentary Affairs, 1-23.

Stockemer, D., LaMontagne, B., and Scruggs, L. 2011. Bribes and Ballots: The Impact of Corruption on Voter Turnout in Democracies. International Political Science Review 34(1): 74-90.

Stockemer, D., and Scruggs, L. 2012. Income Inequality, Development and Electoral Turnout- New Evidence on a Burgeoning Debate. Electoral Studies, 31: 764-773.

Teorell, J., Charron, N., Dahlberg, S., Holmberg, S., Rothstein, B., Sundin, P., and Svensson, R. 2013. The Quality of Government Dataset, version 30Apr13. University of Gothenburg: The Quality of Government Institute, http://www.qog.pol.gu.se

Table 1. Variable description

\begin{tabular}{|l|l|c|c|}
\hline \multicolumn{1}{|c|}{ Variable } & \multicolumn{1}{|c|}{ Definition Source } & \multicolumn{1}{c|}{$\begin{array}{c}\text { Time } \\
\text { coverage }\end{array}$} & $\begin{array}{c}\text { Number of } \\
\text { cases }\end{array}$ \\
\hline \multicolumn{1}{|c|}{$\begin{array}{c}\text { Socio } \\
\text { Temographic }\end{array}$} & IDEA & $1946-2012$ & 2337 \\
\hline logGDP & $\begin{array}{l}\text { GDP at purchaser's prices is the sum of gross value added by } \\
\text { all resident producers in the economy plus any product taxes } \\
\text { and minus any subsidies not included in the value of the } \\
\text { products. It is calculated without making deductions for } \\
\text { depreciation of fabricated assets or for depletion and } \\
\text { degradation of natural resources. Data are in current U.S. } \\
\text { dollars. Dollar figures for GDP are converted from domestic } \\
\text { currencies using single year official exchange rates. For a few } \\
\text { countries where the official exchange rate does not reflect the } \\
\text { rate effectively applied to actual foreign exchange transactions, } \\
\text { an alternative conversion factor is used. (QoG) }\end{array}$ & $1961-2011$ & 2125 \\
\hline $\begin{array}{l}\text { Population (1000's at mid-year). Logarithm. (QoG) } \\
\text { logpopulation } \\
\text { (poncentration }\end{array}$ & $\begin{array}{l}\text { Urban population refers to people living in urban areas as } \\
\text { defined by national statistical offices. It is calculated using } \\
\text { World Bank population estimates and urban ratios from the } \\
\text { United Nations World Urbanization Prospects. (QoG) }\end{array}$ & $1961-2011$ & 1465 \\
\hline $\begin{array}{l}\text { Population } \\
\text { homogeneity }\end{array}$ & $\begin{array}{l}\text { Reflects probability that two randomly selected people from a } \\
\text { given country will not belong to the same religious group. The }\end{array}$ & $1946-2012$ & 1700 \\
\hline
\end{tabular}




\begin{tabular}{|c|c|c|c|}
\hline (pophomog) & higher the number, the more fractionalized society. (QoG) & & \\
\hline Previous turnout & Lagged dependent variable & & 1753 \\
\hline \multicolumn{4}{|l|}{ Institutional } \\
\hline Compulsory vote & Is voting compulsory? & $1946-2012$ & 1933 \\
\hline $\begin{array}{l}\text { Presidential or } \\
\text { parliamentary }\end{array}$ & Characteristic of the election : presidential or parliamentary & $1946-2012$ & 1935 \\
\hline Electoral formula & $\begin{array}{l}\text { Variable that indicates the type of electoral system used: } \\
\text { majoritarian vs proportional and mixed. Bormann and Golder } \\
\text { (2013) }\end{array}$ & $1950-2008$ & 1119 \\
\hline Number of parties & $\begin{array}{l}\text { Effective number of electoral parties based on the following } \\
\text { formula from Laakso and Taagepera (1979). Values for } \\
\text { democratic elections (1950- 2000) from Golder (2005). }\end{array}$ & & \\
\hline \multicolumn{4}{|l|}{ Political } \\
\hline Incumbent run & $\begin{array}{l}\text { Was the office of the incumbent leader contested in this } \\
\text { election? }\end{array}$ & $1946-2010$ & 1379 \\
\hline \multicolumn{4}{|l|}{$\begin{array}{c}\text { Democracy } \\
\text { variables }\end{array}$} \\
\hline $\begin{array}{l}\text { Cheibub, Gandhi } \\
\text { and Vreeland } \\
\text { definition of } \\
\text { democracy } \\
\text { democracy }\end{array}$ & $\begin{array}{l}\text { A regime is considered a democracy if the executive and the } \\
\text { legislature is directly or indirectly elected by popular vote, } \\
\text { multiple parties are allowed, there is de facto existence of } \\
\text { multiple parties outside of regime front, there are multiple } \\
\text { parties within the legislature, and there has been no } \\
\text { consolidation of incumbent advantage (e.g. unconstitutional } \\
\text { closing of the lower house or extension of incumbent's term by } \\
\text { postponing of subsequent elections). Cheibub, Gandhi and } \\
\text { Vreeland (2010) Transition years are coded as the regime that } \\
\text { emerges in that year. (QoG) }\end{array}$ & 1946-2008 & 2424 \\
\hline $\begin{array}{l}\text { democracy2 } \\
\text { democracy3 }\end{array}$ & $\begin{array}{l}\text { Democracy (Freedom House/Imputed Polity). Scale ranges } \\
\text { from } 0-10 \text { where } 0 \text { is least democratic and } 10 \text { most democratic. } \\
\text { Average of Freedom House (fh_pr and fh_cl) is transformed to } \\
\text { a scale } 0-10 \text { and Polity (p_polity2) is transformed to a scale } 0- \\
10 \text {. These variables are averaged into fh_polity2. } \\
\text { The imputed version has imputed values for countries where } \\
\text { data on Polity is missing by regressing Polity on the average } \\
\text { Freedom House measure. Hadenius \& Teorell (2005) show that } \\
\text { this average index performs better both in terms of validity and } \\
\text { reliability than its constituent parts. }\end{array}$ & $1972-2012$ & 1996 \\
\hline
\end{tabular}


Table 2. Turnout determinants

\begin{tabular}{lccc}
\hline MODELS & $(1)$ & $(2)$ & $(3)$ \\
\hline Log GDP & -0.505 & 0.154 & 0.421 \\
Log population & $(0.450)$ & $(1.318)$ & $(0.555)$ \\
& $-1.100^{* *}$ & -0.725 & $-1.192^{* *}$ \\
Population concen & $(0.494)$ & $(1.399)$ & $(0.571)$ \\
& $0.128^{* *}$ & $-0.131^{*}$ & -0.0496 \\
Population homog & $(0.0620)$ & $(0.0687)$ & $(0.0335)$ \\
& $-16.52^{* * *}$ & -3.134 & $-12.78^{* * *}$ \\
Election type & $(1.877)$ & $(4.979)$ & $(3.292)$ \\
& $3.294^{* *}$ & 0.346 & 1.692 \\
Compulsory voting & $(1.586)$ & $(3.432)$ & $(1.959)$ \\
& $4.780^{* * *}$ & 2.376 & $2.702^{* *}$ \\
Incumbent run & $(1.424)$ & $(2.066)$ & $(1.267)$ \\
& $7.824^{* * *}$ & $6.247 * *$ & $6.950^{* * *}$ \\
Democracy & $(1.442)$ & $(2.738)$ & $(1.426)$ \\
& & & $2.781^{* *}$ \\
Constant & & & $(1.138)$ \\
& $85.67^{* * *}$ & $69.91^{* * *}$ & $71.79 * * *$ \\
Observations & $(4.665)$ & $(13.13)$ & $(8.935)$ \\
R-squared & & & \\
Years covered & 942 & 477 & 1,419 \\
Number of countries & 0.882 & 0.830 & 0.832 \\
\hline
\end{tabular}

Standard errors in parentheses

$* * * \mathrm{p}<0.01, * * \mathrm{p}<0.05, * \mathrm{p}<0.1$

Table 3. Robustness checks.

\begin{tabular}{lccccc}
\hline MODELS & $(3)$ & $(4)$ & $(5)$ & $(6)$ & $(7)$ \\
\hline Log GDP & 0.421 & $-1.199^{*}$ & -0.993 & -0.197 & -0.374 \\
& $(0.555)$ & $(0.656)$ & $(0.650)$ & $(0.575)$ & $(0.391)$ \\
Log population & $-1.192^{* *}$ & 0.443 & 0.0973 & 0.0874 & -0.0939 \\
& $(0.571)$ & $(0.671)$ & $(0.667)$ & $(0.572)$ & $(0.398)$ \\
Population concen & -0.0496 & -0.00304 & -0.00192 & -0.0522 & 0.0251 \\
& $(0.0335)$ & $(0.0428)$ & $(0.0386)$ & $(0.0558)$ & $(0.0226)$ \\
Population homog & $-12.78^{* * *}$ & $-13.23^{* * *}$ & $-13.82^{* * *}$ & $-11.45^{* * *}$ & $-2.917^{*}$ \\
& $(3.292)$ & $(3.745)$ & $(3.623)$ & $(3.521)$ & $(1.634)$ \\
Election type & 1.692 & $3.397^{*}$ & $3.596^{*}$ & & $2.926^{* * *}$ \\
& $(1.959)$ & $(1.934)$ & $(1.888)$ & & $(0.752)$ \\
Compulsory voting & $2.702^{* *}$ & $5.602^{* * *}$ & $4.723^{* * *}$ & $3.204^{* *}$ & $2.709^{* * *}$ \\
& $(1.267)$ & $(1.380)$ & $(1.353)$ & $(1.343)$ & $(0.702)$ \\
Incumbent run & $6.950^{* * *}$ & $8.130^{* * *}$ & $8.291^{* * *}$ & $9.566^{* * *}$ & $5.038^{* * *}$ \\
& $(1.426)$ & $(1.253)$ & $(1.314)$ & $(1.317)$ & $(0.889)$ \\
Democracy & $2.781^{* *}$ & & & $4.082^{* * *}$ & 1.359 \\
Democracy2 & $(1.138)$ & & & $(1.471)$ & $(0.974)$
\end{tabular}


Democracy3

Number of parties

Majoritarian

Previous turnout

Constant

Observations

R-squared

Years Covered

Number of countries

$3.393 * * *$

(1.064)

$$
\begin{gathered}
0.000108 \\
(0.218) \\
-4.730 * * * \\
(1.537)
\end{gathered}
$$

$0.634 * * *$

(0.0606)

71.79***

$79.07 * * *$

$80.09 * * *$

$66.29 * * *$

$26.43 * * *$

(8.935)

(9.383)

(9.378)

(8.399)

(6.010)

\begin{tabular}{ccccc}
1,419 & 1,325 & 1,325 & 870 & 1,178 \\
0.832 & 0.820 & 0.827 & 0.829 & 0.898 \\
$1961-2008$ & $1972-2011$ & $1972-2011$ & $1961-2008$ & $1961-2008$ \\
148 & 148 & 148 & 124 & 139 \\
\hline
\end{tabular}

Standard errors in parentheses

*** $\mathrm{p}<0.01,{ }^{* *} \mathrm{p}<0.05,{ }^{*} \mathrm{p}<0.1$

Graph 1. Turnout in democracies 1945-2008 


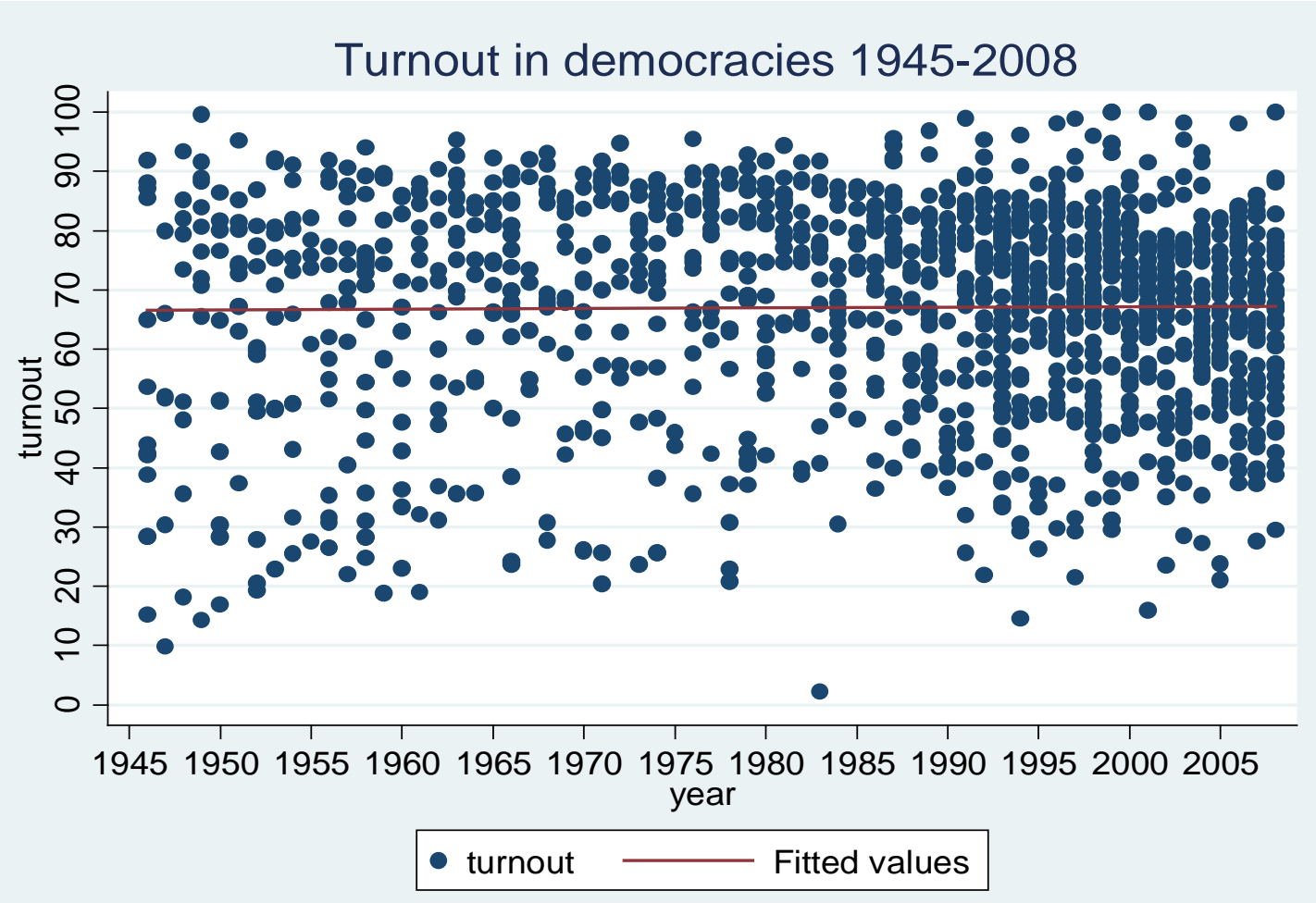

Graph 2. Turnout in non-democracies 1945-2008

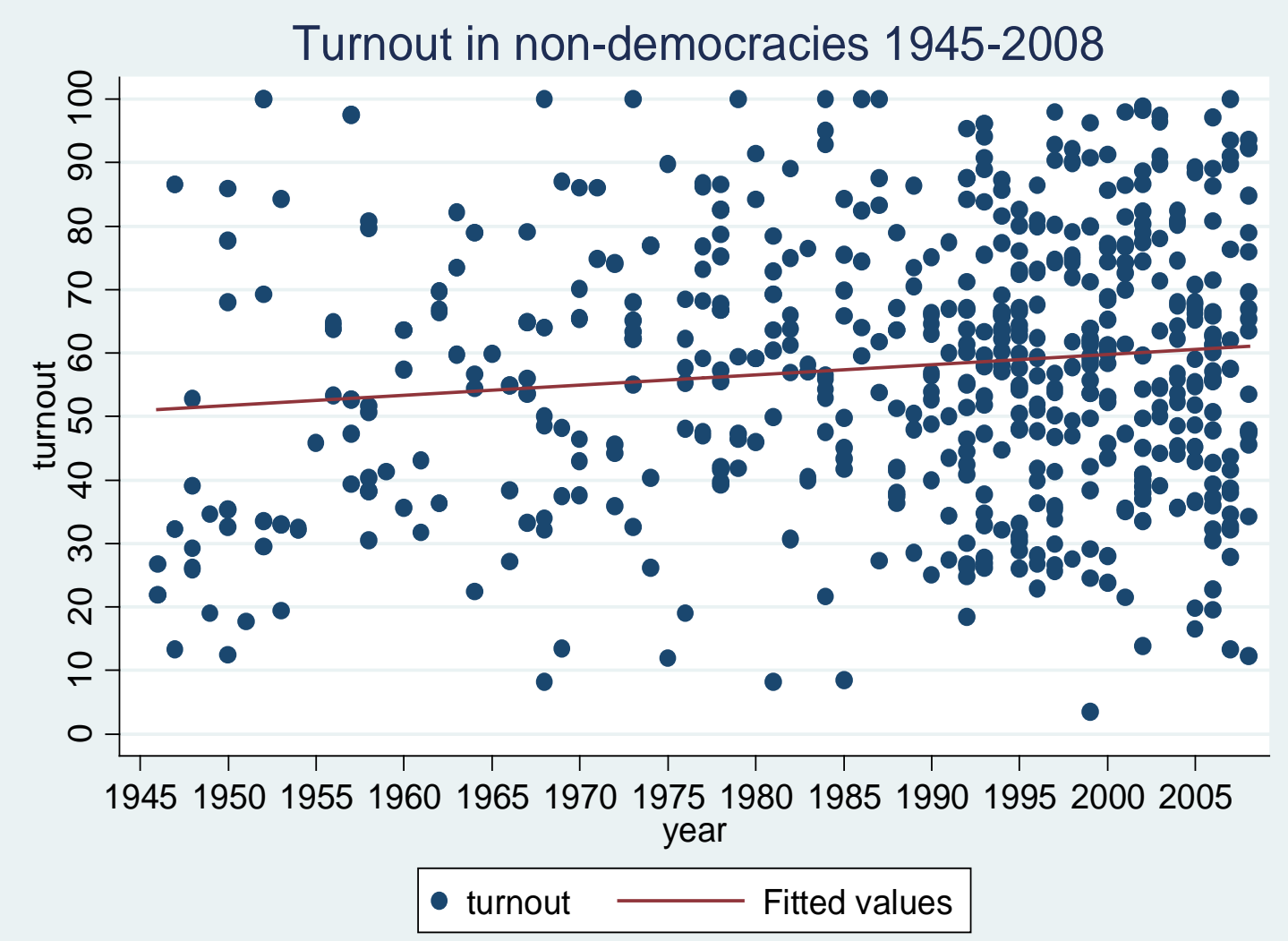




\section{Elections included}

\begin{tabular}{|c|c|c|c|c|c|c|c|c|c|c|}
\hline Afghanistan & 2004 & 2005 & & & & & & & & \\
\hline Albania & 1991 & 1992 & 1996 & 1997 & 2001 & 2005 & & & & \\
\hline Algeria & 1995 & 1997 & 1999 & 2002 & 2004 & 2007 & & & & \\
\hline Angola & 1992 & 2008 & & & & & & & & \\
\hline Argentina & 1962 & 1963 & 1965 & 1973 & 1983 & 1985 & 1987 & 1989 & 1991 & 1993 \\
\hline & 1995 & 1997 & 1999 & 2001 & 2003 & 2005 & 2007 & & & \\
\hline Armenia & 1995 & 1996 & 1998 & 1999 & 2003 & 2007 & 2008 & & & \\
\hline Australia & 1961 & 1963 & 1966 & 1969 & 1972 & 1974 & 1975 & 1977 & 1980 & 1983 \\
\hline & 1984 & 1987 & 1990 & 1993 & 1996 & 1998 & 2001 & 2004 & 2007 & \\
\hline Austria & 1962 & 1963 & 1965 & 1966 & 1970 & 1971 & 1974 & 1975 & 1979 & 1980 \\
\hline & 1983 & 1986 & 1990 & 1992 & 1994 & 1995 & 1998 & 1999 & 2002 & 2004 \\
\hline & 2006 & 2008 & & & & & & & & \\
\hline Azerbaijan & 1993 & 1995 & 1998 & 2000 & 2003 & 2005 & 2006 & 2008 & & \\
\hline Bahrain & 1973 & 2002 & 2006 & & & & & & & \\
\hline Bangladesh & 1973 & 1979 & 1981 & 1986 & 1988 & 1991 & 1996 & 2001 & 2008 & \\
\hline Belarus & 1994 & 1995 & 2000 & 2001 & 2004 & 2006 & 2008 & & & \\
\hline Belgium & 1961 & 1965 & 1968 & 1971 & 1974 & 1977 & 1978 & 1981 & 1985 & 1987 \\
\hline & 1991 & 1995 & 1999 & 2003 & 2007 & & & & & \\
\hline Benin & 1991 & 1995 & 1996 & 1999 & 2001 & 2003 & 2006 & 2007 & & \\
\hline Bhutan & 2008 & & & & & & & & & \\
\hline Bolivia & 1962 & 1964 & 1966 & 1978 & 1979 & 1980 & 1985 & 1989 & 1993 & 1997 \\
\hline & 2002 & 2005 & & & & & & & & \\
\hline Bosnia and $\mathrm{He}$ & zegovin & & 1996 & 1998 & 2000 & 2002 & 2006 & & & \\
\hline Botswana & 1969 & 1974 & 1979 & 1984 & 1989 & 1994 & 1999 & 2004 & & \\
\hline Brazil & 1962 & 1966 & 1970 & 1978 & 1982 & 1986 & 1989 & 1990 & 1994 & 1998 \\
\hline & 2002 & 2006 & & & & & & & & \\
\hline Bulgaria & 1992 & 1994 & 1996 & 1997 & 2001 & 2005 & 2006 & & & \\
\hline Burkina Faso & 1970 & 1978 & 1991 & 1992 & 1997 & 1998 & 2002 & 2005 & 2007 & \\
\hline Burundi & & 1993 & 2005 & & & & & & & \\
\hline Cambodia & 1998 & 2003 & 2008 & & & & & & & \\
\hline Cameroon & 1988 & 1992 & 1997 & 2002 & 2004 & 2007 & & & & \\
\hline Canada & 1962 & 1963 & 1965 & 1968 & 1972 & 1974 & 1979 & 1980 & 1984 & 1988 \\
\hline & 1993 & 1997 & 2000 & 2004 & 2006 & 2008 & & & & \\
\hline Central Africa & Republ & & & 1993 & 1998 & 1999 & 2005 & & & \\
\hline Chad & 1996 & 1997 & 2001 & 2002 & 2006 & & & & & \\
\hline Chile & 1961 & 1964 & 1965 & 1969 & 1970 & 1973 & 1989 & 1993 & 1997 & 2000 \\
\hline & 2001 & 2005 & 2006 & & & & & & & \\
\hline Colombia & 1970 & 1974 & 1978 & 1982 & 1986 & 1990 & 1991 & 1994 & 1998 & 2002 \\
\hline & 2006 & & & & & & & & & \\
\hline Comoros & 1987 & 1996 & 2002 & 2006 & & & & & & \\
\hline Congo, Demo & atic Re & oublic o & & 2006 & & & & & & \\
\hline Costa Rica & 1962 & 1966 & 1970 & 1974 & 1978 & 1982 & 1986 & 1990 & 1994 & 1998 \\
\hline & 2002 & 2006 & & & & & & & & \\
\hline Croatia & 1992 & 1995 & 1997 & 2000 & 2003 & 2005 & 2007 & & & \\
\hline Cuba & 1993 & & & & & & & & & \\
\hline Cyprus & 1976 & 1981 & 1985 & 1991 & 1993 & 1996 & 1998 & 2001 & 2003 & 2006 \\
\hline & 2008 & & & & & & & & & \\
\hline Czech Republ & & 1996 & 1998 & 2002 & 2006 & & & & & \\
\hline Côte d'Ivoire & 1990 & 1995 & 2000 & & & & & & & \\
\hline
\end{tabular}




\begin{tabular}{|c|c|c|c|c|c|c|c|c|c|c|}
\hline \multirow[t]{2}{*}{ Denmark } & 1964 & 1966 & 1968 & 1971 & 1973 & 1975 & 1977 & 1979 & 1981 & 1984 \\
\hline & 1987 & 1988 & 1990 & 1994 & 1998 & 2001 & 2005 & 2007 & & \\
\hline \multicolumn{2}{|c|}{ Djibouti } & 1992 & 1993 & 1997 & 1999 & 2003 & 2005 & 2008 & & \\
\hline \multirow{2}{*}{\multicolumn{2}{|c|}{ Dominican Republic }} & 1962 & 1966 & 1970 & 1974 & 1978 & 1982 & 1986 & 1990 & 1994 \\
\hline & & 1996 & 1998 & 2000 & 2002 & 2004 & 2006 & 2008 & & \\
\hline \multirow[t]{2}{*}{ Ecuador } & 1962 & 1968 & 1978 & 1979 & 1984 & 1986 & 1988 & 1990 & 1992 & 1994 \\
\hline & 1996 & 1998 & 2002 & 2006 & & & & & & \\
\hline Egypt & 1976 & 1984 & 1987 & 1990 & 1995 & 2005 & & & & \\
\hline \multirow[t]{2}{*}{ El Salvador } & 1966 & 1967 & 1968 & 1970 & 1972 & 1977 & 1978 & 1984 & 1985 & 1988 \\
\hline & 1989 & 1991 & 1994 & 1997 & 1999 & 2000 & 2003 & 2004 & 2006 & \\
\hline \multicolumn{2}{|c|}{ Equatorial Guinea } & 1999 & 2002 & 2004 & & & & & & \\
\hline Estonia & 1992 & 1995 & 1999 & 2003 & 2007 & & & & & \\
\hline Ethiopia & 1995 & 2000 & 2005 & & & & & & & \\
\hline Fiji & 1992 & 1994 & 1999 & 2001 & 2006 & & & & & \\
\hline \multirow[t]{2}{*}{ Finland } & 1962 & 1966 & 1968 & 1970 & 1972 & 1975 & 1978 & 1979 & 1982 & 1983 \\
\hline & 1987 & 1988 & 1991 & 1994 & 1995 & 1999 & 2000 & 2003 & 2006 & 2007 \\
\hline \multirow[t]{2}{*}{ France } & 1965 & 1967 & 1968 & 1969 & 1973 & 1974 & 1978 & 1981 & 1986 & 1988 \\
\hline & 1993 & 1995 & 1997 & 2002 & 2007 & & & & & \\
\hline Gabon & 1993 & 1998 & 2005 & & & & & & & \\
\hline \multirow[t]{2}{*}{ Gambia } & 1972 & 1977 & 1982 & 1987 & 1992 & 1996 & 1997 & 2001 & 2002 & 2006 \\
\hline & 2007 & & & & & & & & & \\
\hline Georgia & 1992 & 1995 & 1999 & 2000 & 2003 & 2004 & 2008 & & & \\
\hline Germany & 1994 & 1998 & 2002 & 2005 & & & & & & \\
\hline Ghana & 1969 & 1979 & 1992 & 1996 & 2000 & 2004 & 2008 & & & \\
\hline \multirow[t]{2}{*}{ Greece } & 1961 & 1963 & 1964 & 1974 & 1977 & 1981 & 1985 & 1989 & 1993 & 1996 \\
\hline & 2000 & 2004 & 2007 & & & & & & & \\
\hline \multirow[t]{2}{*}{ Guatemala } & 1961 & 1966 & 1970 & 1974 & 1978 & 1982 & 1985 & 1990 & 1991 & 1994 \\
\hline & 1995 & 1999 & 2003 & 2007 & & & & & & \\
\hline Guinea & 1993 & 1995 & 1998 & 2002 & 2003 & & & & & \\
\hline Guinea-Bissau & 1994 & 1999 & 2004 & 2005 & 2008 & & & & & \\
\hline Guyana & 1968 & 1973 & 1980 & 1985 & 1992 & 1997 & 2001 & 2006 & & \\
\hline Haiti & 1988 & 1990 & 1995 & 2000 & 2006 & & & & & \\
\hline Honduras & 1971 & 1981 & 1985 & 1989 & 1993 & 1997 & 2001 & 2005 & & \\
\hline Hungary & 1990 & 1994 & 1998 & 2002 & 2006 & & & & & \\
\hline \multirow[t]{2}{*}{ India } & 1962 & 1967 & 1971 & 1977 & 1980 & 1984 & 1989 & 1991 & 1996 & 1998 \\
\hline & 1999 & 2004 & & & & & & & & \\
\hline Indonesia & 1971 & 1977 & 1982 & 1987 & 1992 & 1997 & 1999 & 2004 & & \\
\hline \multicolumn{4}{|c|}{ Iran, Islamic Republic of } & 1992 & 1993 & 1996 & 2001 & 2005 & 2008 & \\
\hline Iraq & 2005 & & & & & & & & & \\
\hline \multirow{2}{*}{ Ireland } & 1961 & 1965 & 1966 & 1969 & 1973 & 1977 & 1981 & 1982 & 1987 & 1989 \\
\hline & 1992 & 1997 & 2002 & 2007 & & & & & & \\
\hline \multirow[t]{2}{*}{ Israel } & 1961 & 1965 & 1969 & 1973 & 1977 & 1981 & 1984 & 1988 & 1992 & 1996 \\
\hline & 1999 & 2003 & 2006 & & & & & & & \\
\hline \multirow[t]{2}{*}{ Italy } & 1963 & 1968 & 1972 & 1976 & 1979 & 1983 & 1987 & 1992 & 1994 & 1996 \\
\hline & 2001 & 2006 & 2008 & & & & & & & \\
\hline Jamaica & 1967 & 1972 & 1976 & 1980 & 1983 & 1989 & 1993 & 1997 & 2002 & 2007 \\
\hline Japan & 1963 & 1967 & 1969 & 1972 & 1976 & 1979 & 1980 & 1983 & 1986 & 1990 \\
\hline & 1993 & 1996 & 2003 & 2005 & & & & & & \\
\hline Jordan & 1989 & 1993 & 1997 & 2003 & 2007 & & & & & \\
\hline Kazakhstan & 1995 & 1999 & 2004 & 2005 & 2007 & & & & & \\
\hline Kenya & 1992 & 1997 & 2002 & 2007 & & & & & & \\
\hline Korea, Republi & c of & 1967 & 1971 & 1973 & 1978 & 1981 & 1985 & 1988 & 1992 & 1996 \\
\hline & & 1997 & 2000 & 2002 & 2004 & 2007 & 2008 & & & \\
\hline & 1975 & 1981 & 1985 & 1992 & 1996 & 2006 & 2008 & & & \\
\hline Kyrgyzstan & 1995 & 2000 & 2005 & 2007 & & & & & & \\
\hline
\end{tabular}




\begin{tabular}{|c|c|c|c|c|c|c|c|c|c|c|c|}
\hline \multicolumn{3}{|c|}{ Lao People's Dem. Republic } & \multicolumn{3}{|l|}{2006} & & & & & & \\
\hline Latvia & 1993 & 1995 & 1998 & 2002 & 2006 & & & & & & \\
\hline Lebanon & 1992 & 1996 & 2000 & 2005 & & & & & & & \\
\hline Lesotho & 1970 & 1993 & 1998 & 2002 & 2007 & & & & & & \\
\hline Liberia & 2005 & & & & & & & & & & \\
\hline Lithuania & 1992 & 1993 & 1996 & 1998 & 2000 & 2003 & 2004 & 2008 & & & \\
\hline Macedonia, fol & mer $\mathrm{Yl}$ & goslav & epublic & (1993-) & 1994 & 1998 & 1999 & 2002 & 2004 & 2006 & 2008 \\
\hline Madagascar & 1970 & 1989 & 1992 & 1993 & 1996 & 1998 & 2001 & 2002 & 2006 & & \\
\hline Malawi & 1994 & 1999 & 2004 & & & & & & & & \\
\hline Malaysia & 1974 & 1978 & 1982 & 1986 & 1990 & 1995 & 1999 & 2004 & 2008 & & \\
\hline Mali & 1992 & 1997 & 2002 & 2007 & & & & & & & \\
\hline Mauritania & 1992 & 1996 & 1997 & 2001 & 2003 & 2006 & 2007 & & & & \\
\hline Mauritius & 1976 & 1982 & 1983 & 1987 & 1991 & 1995 & 2000 & 2005 & & & \\
\hline Mexico & 1961 & 1964 & 1967 & 1970 & 1973 & 1976 & 1979 & 1982 & 1985 & 1988 & \\
\hline & 1991 & 1994 & 1997 & 2000 & 2003 & 2006 & & & & & \\
\hline Moldova, Repı & blic of & 1994 & 1996 & 2001 & 2005 & & & & & & \\
\hline Mongolia & 1990 & 1992 & 1993 & 1996 & 1997 & 2000 & 2001 & 2004 & 2005 & 2008 & \\
\hline Morocco & 1970 & 1977 & 1984 & 1993 & 1997 & 2002 & 2007 & & & & \\
\hline Mozambique & 1994 & 1999 & 2004 & & & & & & & & \\
\hline Myanmar & 1990 & & & & & & & & & & \\
\hline Namibia & 1994 & 1999 & 2004 & & & & & & & & \\
\hline Nepal & 1981 & 1986 & 1991 & 1994 & 1999 & & & & & & \\
\hline Netherlands & 1963 & 1967 & 1971 & 1972 & 1977 & 1981 & 1982 & 1986 & 1989 & 1994 & \\
\hline & 1998 & 2002 & 2003 & 2006 & & & & & & & \\
\hline New Zealand & 1963 & 1966 & 1969 & 1972 & 1975 & 1978 & 1981 & 1984 & 1987 & 1990 & \\
\hline & 1993 & 1996 & 1999 & 2002 & 2005 & 2008 & & & & & \\
\hline Nicaragua & 1963 & 1967 & 1974 & 1984 & 1990 & 1996 & 2001 & 2006 & & & \\
\hline Niger & 1993 & 1995 & 1996 & 1999 & 2004 & & & & & & \\
\hline Nigeria & 1979 & 1983 & 1993 & 1999 & 2003 & 2007 & & & & & \\
\hline Norway & 1961 & 1965 & 1969 & 1973 & 1977 & 1981 & 1985 & 1989 & 1993 & 1997 & \\
\hline & 2001 & 2005 & & & & & & & & & \\
\hline Pakistan & 1977 & 1985 & 1988 & 1990 & 1993 & 1997 & 2002 & 2008 & & & \\
\hline Panama & 1964 & 1968 & 1984 & 1989 & 1994 & 1999 & 2004 & & & & \\
\hline Papua New Gu & inea & 1977 & 1982 & 1987 & 1992 & 1997 & & & & & \\
\hline Paraguay & $\begin{array}{l}1963 \\
2008\end{array}$ & 1968 & 1973 & 1978 & 1983 & 1988 & 1989 & 1993 & 1998 & 2003 & \\
\hline Peru & 1962 & 1963 & 1980 & 1985 & 1990 & 1995 & 2000 & 2001 & 2006 & & \\
\hline Philippines & 1967 & 1969 & 1978 & 1987 & 1992 & 1995 & 1998 & 2001 & 2004 & 2007 & \\
\hline Poland & 1989 & 1990 & 1991 & 1993 & 1995 & 1997 & 2000 & 2001 & 2005 & 2007 & \\
\hline Portugal & 1976 & 1979 & 1980 & 1983 & 1985 & 1986 & 1987 & 1991 & 1995 & 1996 & \\
\hline & 2001 & 2002 & 2005 & 2006 & & & & & & & \\
\hline Republic of Th & e Cong & (Brazz & iville) & 2002 & & & & & & & \\
\hline Romania & 1992 & 1996 & 2000 & 2004 & 2008 & & & & & & \\
\hline Russian Federa & tion & 1993 & 1995 & 1996 & 1999 & 2000 & 2003 & 2004 & 2007 & 2008 & \\
\hline Rwanda & & 2003 & 2008 & & & & & & & & \\
\hline Senegal & 1963 & 1978 & 1983 & 1988 & 1993 & 1998 & 2000 & 2001 & 2007 & & \\
\hline Sierra Leone & 1967 & 1977 & 1996 & 2002 & 2007 & & & & & & \\
\hline Singapore & $\begin{array}{l}1968 \\
2006\end{array}$ & 1972 & 1976 & 1980 & 1984 & 1988 & 1991 & 1993 & 1997 & 2001 & \\
\hline Slovakia & 1994 & 1999 & 2002 & 2004 & 2006 & & & & & & \\
\hline Slovenia & 1992 & 1996 & 1997 & 2000 & 2002 & 2004 & 2007 & 2008 & & & \\
\hline Somalia & 1969 & 1979 & & & & & & & & & \\
\hline South Africa & 1994 & 1999 & 2004 & & & & & & & & \\
\hline Spain & 1977 & 1979 & 1982 & 1986 & 1989 & 1993 & 1996 & 2000 & 2004 & 2008 & \\
\hline
\end{tabular}




\begin{tabular}{|c|c|c|c|c|c|c|c|c|c|c|}
\hline Sri Lanka & $\begin{array}{l}1965 \\
2005\end{array}$ & 1970 & 1977 & 1988 & 1989 & 1994 & 1999 & 2000 & 2001 & 2004 \\
\hline Sudan & 1996 & & & & & & & & & \\
\hline \multirow[t]{2}{*}{ Sweden } & 1964 & 1968 & 1970 & 1973 & 1976 & 1979 & 1982 & 1985 & 1988 & 1991 \\
\hline & 1994 & 1998 & 2002 & 2006 & & & & & & \\
\hline \multirow[t]{2}{*}{ Switzerland } & 1963 & 1967 & 1971 & 1975 & 1979 & 1983 & 1987 & 1991 & 1995 & 1999 \\
\hline & 2003 & 2007 & & & & & & & & \\
\hline \multicolumn{2}{|c|}{ Syrian Arab Republic } & 1994 & 1998 & 2003 & 2007 & & & & & \\
\hline Tajikistan & 1994 & 1995 & 2000 & 2005 & 2006 & & & & & \\
\hline \multicolumn{3}{|c|}{ Tanzania, United Republic of } & 1995 & 2000 & 2005 & & & & & \\
\hline \multirow[t]{2}{*}{ Thailand } & 1969 & 1975 & 1976 & 1983 & 1986 & 1988 & 1992 & 1995 & 1996 & 2001 \\
\hline & 2005 & 2006 & 2007 & & & & & & & \\
\hline Togo & 1985 & 1990 & 1994 & 1998 & 2002 & 2003 & 2005 & 2007 & & \\
\hline \multirow{2}{*}{\multicolumn{2}{|c|}{ Trinidad and Tobago }} & 1966 & 1971 & 1976 & 1981 & 1986 & 1991 & 1995 & 2000 & 2001 \\
\hline & & 2002 & 2007 & & & & & & & \\
\hline Tunisia & 1981 & 1986 & 1989 & 1994 & 1999 & 2004 & & & & \\
\hline \multirow[t]{2}{*}{ Turkey } & 1961 & 1969 & 1973 & 1977 & 1983 & 1987 & 1991 & 1995 & 1999 & 2002 \\
\hline & 2007 & & & & & & & & & \\
\hline Turkmenistan & 2004 & 2007 & & & & & & & & \\
\hline Uganda & 1980 & 1996 & 2001 & 2006 & & & & & & \\
\hline Ukraine & 1994 & 1998 & 1999 & 2002 & 2004 & 2006 & 2007 & & & \\
\hline \multirow{2}{*}{\multicolumn{2}{|c|}{ United Kingdom }} & 1964 & 1966 & 1970 & 1974 & 1979 & 1983 & 1987 & 1992 & 1997 \\
\hline & & 2001 & 2005 & & & & & & & \\
\hline \multirow[t]{3}{*}{ United States } & 1962 & 1964 & 1966 & 1968 & 1970 & 1972 & 1974 & 1976 & 1978 & 1980 \\
\hline & 1982 & 1984 & 1986 & 1988 & 1990 & 1992 & 1994 & 1996 & 1998 & 2000 \\
\hline & 2002 & 2004 & 2006 & 2008 & & & & & & \\
\hline Uruguay & 1962 & 1966 & 1971 & 1984 & 1989 & 1994 & 1999 & 2004 & & \\
\hline Uzbekistan & 1994 & 1999 & 2000 & 2004 & & & & & & \\
\hline \multirow[t]{2}{*}{ Venezuela } & 1963 & 1968 & 1973 & 1978 & 1983 & 1988 & 1993 & 1998 & 2000 & 2005 \\
\hline & 2006 & & & & & & & & & \\
\hline Viet Nam & 1992 & 1997 & 2002 & & & & & & & \\
\hline Zambia & 1968 & 1991 & 1996 & 2001 & 2006 & 2008 & & & & \\
\hline Zimbabwe & 1979 & 1980 & 1985 & 1990 & 1995 & 1996 & 2000 & 2002 & 2005 & 2008 \\
\hline
\end{tabular}

